\title{
Multidimensional Model for Vulnerability Assessment of Urban Flooding: An Empirical Study in Pakistan
}

\author{
Irfan Ahmad Rana ${ }^{1} \cdot$ Jayant K. Routray $^{2}$
}

Published online: 27 August 2018

(C) The Author(s) 2018

\begin{abstract}
Urban flooding has become a regular phenomenon in many towns and cities in the Asia Pacific region over the past years. Professionals associated with disaster management and climate change are at the forefront of addressing urban flooding. To reduce flood risks, vulnerability and its components must be understood. Vulnerability assessment methods are diverse and complex, with a varied nature of understanding the key terms used in various contexts, and this diversity ultimately reflects on the interpretation of results in research settings. Diverse interpretations and definitions exist in the disaster risk and climate change literature, complicating the process of astute and comprehensive vulnerability assessment. The main purpose of this study was to quantify vulnerability indicators and develop a multidimensional model for vulnerability assessment. Vulnerability is explored through the lens of five dimensions: social, economic, physical/infrastructural, institutional, and attitudinal. This methodology is applied to urban flooding in Pakistan, to verify the proposed model. Three study sites in urban areas with different population sizes, situated in high-risk flood zones in the Punjab Province of Pakistan were selected for empirical investigation. A household survey was conducted, and
\end{abstract}

Irfan Ahmad Rana

irfanrana90@hotmail.com; iarana@nit.nust.edu.pk

1 Department of Urban and Regional Planning (URP), School of Civil and Environmental Engineering (SCEE), National University of Sciences and Technology (NUST), H-12, Campus, Islamabad, Pakistan

2 Regional and Rural Development Planning (RRDP) and Disaster Preparedness, Mitigation and Management (DPMM), Department of Development and Sustainability, Asian Institute of Technology, Klong Luang, Pathum Thani, Thailand indices were developed for each dimension based on welldefined indicators. The proposed methodology for vulnerability assessment was tested and found operational. This method can be replicated irrespective of spatial scales and can be modified for other disasters by streamlining hazard specific indicators.

Keywords Pakistan P Punjab · Urban flooding · Vulnerability assessment

\section{Introduction}

Vulnerability assessment is an essential part of both disaster risk reduction and sustainability science (Turner et al. 2003; Zhou et al. 2015). Vulnerability has emerged as a widely used concept in global environmental change, disaster risk management, and climate change adaptation (Schröter et al. 2005; Adger 2006; Polsky et al. 2007; Gain et al. 2015). Vulnerability assessment entails both the identification and the reduction of the susceptibilities of the exposed elements. It is deemed a crucial step towards reducing the consequences of natural hazards and disaster risks (Fuchs et al. 2012). Vulnerability is often exacerbated by socioeconomic inequalities, poverty, high population density, lack of awareness, weak institutions, and poor infrastructure (Cutter et al. 2003; Rana and Routray 2016). To minimize the potential harm associated with disasters, communities' vulnerabilities and factors need to be measured (Schröter et al. 2005; Armaş 2012). Recently, interest has been focused on working out vulnerability assessment methodologies (Balica et al. 2012), but these methodologies still require proper refining before they can be included in policies. Vulnerability is multifaceted and includes diverse components, but there is a lack of an integrated 
methodology that fuses all the components together. This study tries to quantify multidimensional vulnerability using social, economic, physical/infrastructural, institutional, and attitudinal dimensions. This multidimensional vulnerability assessment would greatly help in identifying a relevant course of action for disaster risk reduction in exposed communities.

Disasters are occurring with increasing intensity and frequency (Balica et al. 2009). Vulnerability to disasters is one of the most underestimated issues in sustainable urban development. Rapid urbanization has dramatically increased the vulnerabilities and risks of urban inhabitants in already exposed areas (Phung et al. 2016). Under severe threat of climate change, the frequency of flooding is expected to rise in urban areas (IPCC 2012). Urban flooding is putting large populations at risk and is now being thoroughly studied in disaster risk science (Gain et al. 2015; WMO 2015; Rana and Routray 2018).

Ineffective coping mechanisms, rapid urbanization, terrorism, political instabilities, weak disaster initiatives, and lack of awareness are plaguing poor disaster risk management in Pakistan (Rana and Routray 2016; Saqib et al. 2016). Socioeconomic and infrastructure inequalities are also rampant among urban areas (Rana et al. 2017), further worsening the situation. Disaster risk management systems are still reactive, and local institutions are managing disasters on an ad hoc basis (Rana and Routray 2016). In Pakistan, floods are the most widely occurring type of disaster. Out of 145 districts in the country (as of 2010 administrative boundaries), 113 were classified as located in medium to very high flood risk zones (NDMA 2012).

Urban centers are continuously facing an increase in riverine, flash, and pluvial flooding, causing widespread infrastructural damages. Damages of USD 10 billion were estimated by the government as a result of the 2010 floods (Federal Flood Commission 2012) that paralyzed almost half of Pakistan. Economic losses of USD 39 billion as a result of flooding have been estimated for the period from 1950 to 2012 (Federal Flood Commission 2012). This huge flood impact calls for assessing the vulnerabilities of floodprone communities for developing effective disaster risk reduction strategies. Some research has been done on flood vulnerabilities in Pakistan (Rana and Routray 2016; Sadia et al. 2016; Jamshed et al. 2017; Shah et al. 2018), but a multidimensional vulnerability assessment is lacking, particularly for urban communities. This study proposes a methodology for assessing multidimensional vulnerability, and its application to flood-prone urban communities in Pakistan.

\section{Theoretical Background}

This study identifies vulnerability as a multifaceted and multidimensional phenomenon. Diverse definitions and interpretations of vulnerability exist in the scientific literature (Adger 2006; Fuchs et al. 2012; Birkmann et al. 2013). This has led to confusion (Janssen and Ostrom 2006). Numerous models have been developed to explain relationships, causes, and dependencies of vulnerability. Despite the existence of these models for vulnerability assessment, which have evolved over time, no consensus has been achieved on what method works best (Armaş 2012). This study sets itself apart from similar vulnerability assessment studies by incorporating various dimensions that are known to determine vulnerability from the perspective of climate change adaptation and disaster risk science.

\subsection{The Concept of Vulnerability}

In disaster risk science and climate change adaptation, vulnerability is increasingly acknowledged to be a humaninduced phenomenon and has been recognized as the root cause of severe disaster impacts (UNISDR 2004; Wisner et al. 2004; Adger 2006; IPCC 2012). Vulnerability is considered an integral and defining part of disaster risk in many interpretations of disaster risk concepts (Wisner et al. 2004; Birkmann 2006; Birkmann et al. 2013). The operational definition of vulnerability, as conceptualized in this study, is stated by the United Nations International Strategy for Disaster Reduction (UNISDR), which defines vulnerability as "the characteristics and circumstances of a community, system or asset that make it susceptible to the damaging effects of a hazard" (UNISDR 2009). Vulnerability can also be seen as the gaps and weaknesses in the coping strategies that are adopted by a community. Vulnerability also overlaps with other concepts in disaster risk science and climate change, like adaptation, capacities, and resilience (Balica et al. 2009).

\subsection{Models of Vulnerability}

Vulnerability has been viewed through the lens of multiple contexts, dimensions, and spatiotemporal scales, and there is no universal theory or model (Jamshed et al. 2017). Vulnerability models/frameworks are part of climate change adaptation and disaster risk science and general enough to incorporate the urban flooding problem. The hazards-of-place vulnerability model contends that vulnerability is specific to spatial scale and an amalgamation of both biophysical and social dimensions (Cutter et al. 2000). Bohle's (2001) double structure of vulnerability 
tried to explain internal and external aspects of vulnerability. The pressure and release model explains the progression of vulnerability (Wisner et al. 2004). Turner et al.'s (2003) vulnerability framework argued that global environmental change can be seen through the lens of sensitivity, exposure, and resilience. The Bogardi, Birkmann and Cardona Framework (BBC) contended that vulnerabilities must be seen as dynamic phenomena that can be measured within the environmental, social, and economic spheres (Bogardi and Birkmann 2004; Birkmann 2006). An eight-step approach was also suggested for measuring vulnerability (Schröter et al. 2005). Birkmann (2006) broadened the theory of vulnerability by suggesting five spheres, including multidimensional features such as physical, social, economic, institutional, and environmental features. A vulnerability scoping diagram was also proposed (Polsky et al. 2007). The Intergovernmental Panel on Climate Change (IPCC) Special Report on Managing the Risks of Extreme Events and Disasters to Advance Climate Change Adaptation (SREX) framework described vulnerability as a subsequent part of disaster risk and its impact on development in the light of disaster risk management and climate change adaptation (IPCC 2012). Recently, methods for the improvement of vulnerability assessment in Europe with the MOVE (Methods for the Improvement of Vulnerability Assessment in Europe) framework were put forth (Birkmann et al. 2013). All these models have provided confirmation of the multidimensional characteristics of vulnerability and its assessment.

\subsection{Vulnerability Assessment}

Vulnerability assessment is an integral part of the research on climate change adaptation and disaster risk science (Wisner et al. 2004; Adger 2006; Birkmann 2006; IPCC 2012; Birkmann et al. 2013). Researchers have assessed vulnerability from many aspects, such as social vulnerability (Cutter et al. 2003; Wisner et al. 2004; Yoon 2012), physical vulnerability (Thouret et al. 2014; PapathomaKöhle et al. 2017), economic vulnerability (Briguglio 1995; Willroth et al. 2011), institutional vulnerability (López-Martínez et al. 2017), and livelihood vulnerability (Hahn et al. 2009). Under the IPCC approach, exposure, sensitivity, and capacity are also used by researchers to measure vulnerability (Balica et al. 2009; Hahn et al. 2009; Birkmann et al. 2013; Zhou et al. 2015; Phung et al. 2016). Some researchers have inferred vulnerability due to past economic damage trends and potential future losses (Hallegatte et al. 2013). However, the main challenge of vulnerability assessment lies in integrating components, dimensions, and methodologies within different disciplines (Schröter et al. 2005; Polsky et al. 2007; Fuchs et al. 2012). There has been no clear-cut and standardized methodology available for measuring the multidimensional aspects of vulnerability (Mazumdar and Paul 2016). This study tries to accommodate various aspects of vulnerability and focuses on proposing a methodology for multidimensional vulnerability assessment, and testing the methodology in flood-prone urban areas of Pakistan.

While the disaster risk literature has identified and researchers have explored various dimensions of vulnerability, an integrated framework of multidimensional vulnerability has been lacking, especially with respect to including the dimension of attitudinal vulnerability. The most important dimensions are the social and economic vulnerabilities, which is supported by a plethora of literature (Cutter et al. 2003; IPCC 2012). For the risk assessment of large cities, understanding the physical vulnerability of buildings and infrastructure is an essential step towards disaster risk reduction (Armaş 2012; Thouret et al. 2014). Institutional vulnerability is also an important dimension, because it amplifies hazards due to the inefficiency of the different authorities responsible for hazard management (Birkmann et al. 2013). But a proper methodology for assessing institutional vulnerability is still lacking (López-Martínez et al. 2017). Attitudinal vulnerability, with roots in risk perception, incorporates fatalistic beliefs and attitudes that can influence vulnerability (Rana and Routray 2016). A detailed analysis of each vulnerability dimension is needed for effective disaster risk reduction (Fuchs et al. 2012; López-Martínez et al. 2017).

Assessing vulnerability based on indices has recently appeared as a widely used quantitative measure (Tate 2012). A composite index would be appropriate for taking into account various dynamic characteristics of vulnerability, because an index summarizes complex data in a simpler way for any nontechnical person to understand (Birkmann 2006). Steps to develop a composite index include developing a conceptual framework for the composite, identifying relevant indicators, standardizing data for comparative analysis, weighing and aggregating indicators, and conducting uncertainty measures to gauge the robustness of indicators (Adger 2004). These kinds of indices have been criticized by many researchers for overgeneralizing and undermining important factors of vulnerability (Yoon 2012). This study develops a comprehensive multidimensional model for vulnerability assessment using a composite index method.

\section{Application of the Proposed Model}

In the disaster risk and climate change literature, vulnerability has clearly been established as multidimensional (Cutter et al. 2003; Polsky et al. 2007; Yoon 2012), and various qualitative and quantitative methods have been 
defined to explain vulnerability (Fuchs et al. 2012; Birkmann et al. 2013). This study presents a model for assessing the multidimensional vulnerability of urban communities in Pakistan to flooding. Flood-prone zones and three urban centers were identified in Punjab Province using secondary sources. Primary data were collected through questionnaires from households of three urban communities in June and July 2015. An index-based approach was employed for the assessment of the multidimensional vulnerabilities of the households. The equal class interval technique was used to classify household vulnerability into very low, low, moderate, and high levels for comparative analysis with respect to each dimension. Due to the comparative analysis among more than two cities, ANOVA (analysis of variance) was utilized to determine difference, where $p$ value shows the level of significance.

\subsection{Study Area Selection}

Through multistage sampling, three cities of different population sizes (more than 1 million, 0.5 to 1 million, and less than 0.5 million) in highly flood-prone areas were selected in Punjab Province (Fig. 1), the most populous province in Pakistan (2017 estimated population 110 million), home to more than half of Pakistan's population and frequently prone to flooding. Rawalpindi (2017 population 2.1 million) is the fourth most populous metropolitan city of Pakistan. The city is characterized by mixed functions and is exposed to regular pluvial flooding in the monsoon season due to Nullah ${ }^{1}$ Lai. Sialkot (2017 population 656 thousand) is a predominantly industrial city that also experiences pluvial flooding in the rainy season due to Nullah Aik and Nullah Degh. Muzaffargarh (2012 population 226 thousand) specializes in agro-industrial activities. The town is a doab, which is "land between two rivers," between the Indus River in the west and the Chenab River in the east, making it highly prone to riverine flooding. A comparative analysis of these urban areas would help in understanding the vulnerability dynamics and their dimensions in the three different tiers of urban settlement.

\subsection{Sampling}

One community from each of the selected cities-Rawalpindi, Sialkot, and Muzaffargarh-was further chosen for in-depth study based on interviews with the respective city administration, and identified based on proximity to flood hazard sources, frequent severe flooding, and past heavy flood damages. A total of 12,867 households lived in the

\footnotetext{
${ }^{1}$ Drainage channel fed by seasonal rains.
}

three selected communities in 2014 (Punjab Bureau of Statistics 2014). Using the Cochran principle of sampling (Cochran 1977), a minimum of 194 samples were estimated, the confidence level was kept at $95 \%$, with a precision value of 0.07 . A minimum of 64,69 , and 61 samples was required from each flood-prone community of Rawalpindi, Sialkot, and Muzaffargarh, respectively. However, 70 samples from each urban community were taken for comparative analysis, bringing the total to 210 sample households. Using 30 questionnaires, pretesting was done in the field in June 2015 to streamline the questionnaire. After finalizing the questionnaire, attempts were made continuously until 210 valid and necessary samples had been collected. The locations of the three selected study sites-Dhok Ratta in Rawalpindi, Hajipura in Sialkot, and Khangarh City of Muzaffargarh-are shown in Fig. 1.

\subsection{Formulation of a Multidimensional Vulnerability Index}

Urban flooding problems fall under both climate change and disaster risk science, and involve various professionals, such as urban planners, engineers, architects, economists, and ecologists. The vast and intricate dynamics of flooding need comprehensive vulnerability assessment, which should incorporate the multifarious factors that affect the complexities in urban areas. The index-based approach of this study was developed for assessing five dimensions of vulnerability-social, economic, physical/infrastructural, institutional, and attitudinal vulnerability. Indicators were chosen through extensive literature review for each dimension of vulnerability. These indicators were chosen from empirical studies from the disaster risk science and climate change fields. Indicators were scrutinized with a view to local conditions and adjusted accordingly. Seven indicators each were used for social, institutional, and attitudinal vulnerability; 10 indicators for economic vulnerability; and 13 indicators for physical/infrastructural vulnerability. The five dimensions are given equal importance, as all three cities experience flood hazards primarily because of nullahs and rivers. Therefore, an average was calculated for all dimensions, which helped in devising the multidimensional vulnerability index.

The original primary datasets were standardized using respective weights for the computation of the composite index as used in other studies of urban flooding (Thouret et al. 2014; Gain et al. 2015; Rana and Routray 2016). This study also uses a subjective weighting technique to allocate values to classes of phenomena for each indicator and formulates indices based on Eq. 1. 

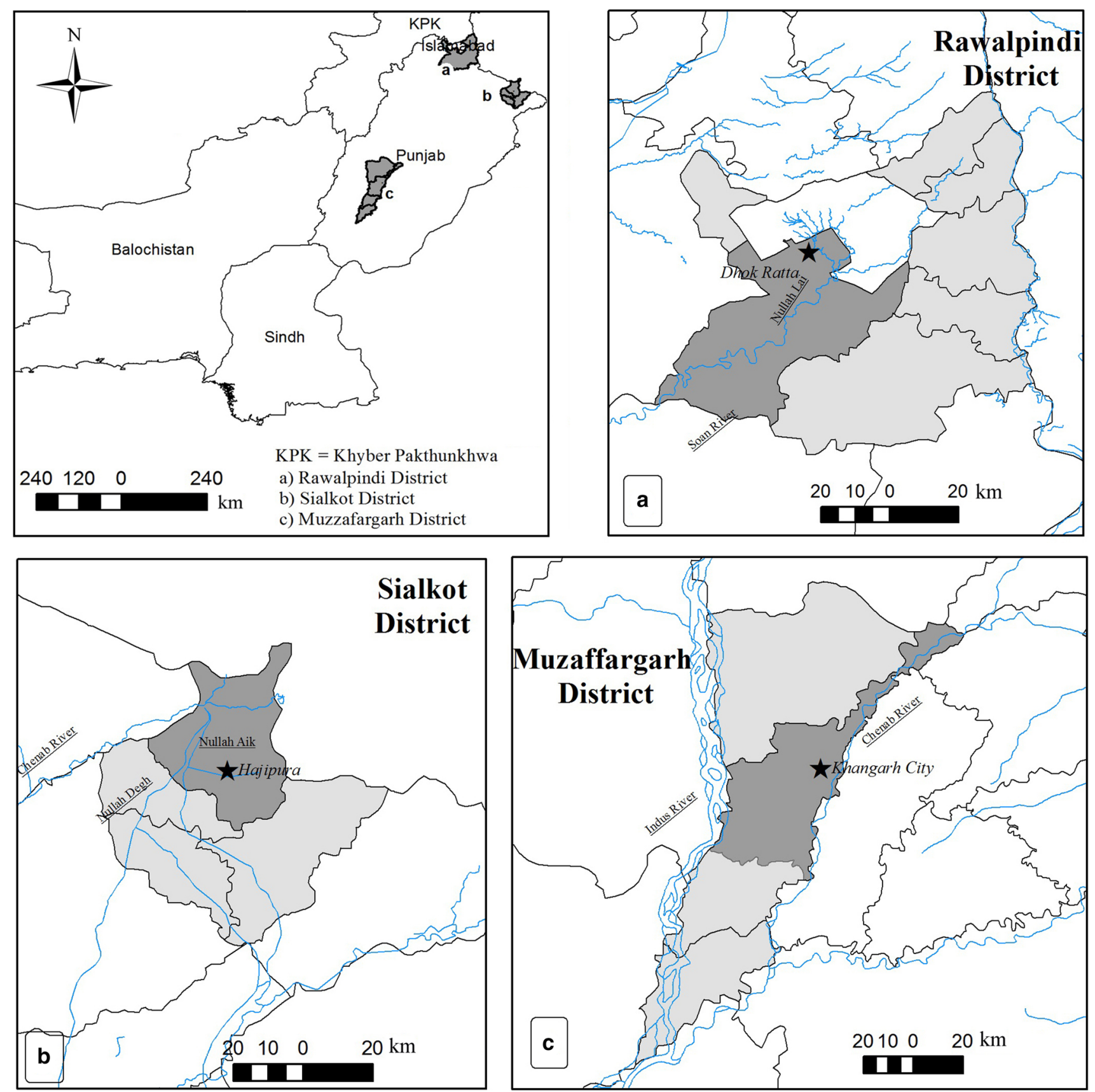

Fig. 1 Map of the study areas in Punjab Province, Pakistan, showing the location of the three selected study sites in a Rawalpindi, b Sialkot, and c Muzaffargarh districts

$$
\begin{aligned}
\mathrm{CI} & =\left(W_{1}+W_{2}+W_{3}+\cdots W_{n}\right) / n \\
& =\sum_{i=1}^{n} W i / n
\end{aligned}
$$

where, $\mathrm{CI}$ is the composite index, $W_{1}$ to $W_{n}$ are respective transformed values assigned to indicators, and $n$ is the number of indicators used for computing the composite index.
Following this general principle, the Social Vulnerability Index (SI), Economic Vulnerability Index (EI), Physical/Infrastructural Vulnerability Index (PI), Institutional Vulnerability Index (II), and Attitudinal Vulnerability Index (AI) were calculated. The Multidimensional Vulnerability Index (MVI) for each household in the study area was calculated using Eq. 2. 
Social Vulnerability Index $(\mathrm{SI})=\sum_{i=1}^{7} \mathrm{SW}_{i} / n \quad(n=7)$

Economic Vulnerability Index (EI)

$$
=\sum_{i=1}^{10} \mathrm{EW}_{i} / n \quad(n=10)
$$

Physical/Infrastructural Vulnerability Index (PI)

$$
=\sum_{i=1}^{13} \mathrm{PW}_{i} / n \quad(n=13)
$$

Institutional Vulnerability Index (II) $=\sum_{i=1}^{7} \mathrm{IW}_{i} / n \quad(n=7)$ Attitudinal Vulnerability Index $(\mathrm{AI})=\sum_{i=1}^{7} \mathrm{AW}_{i} / n \quad(n=7)$ Multidimensional Vulnerability Index (MVI)

$$
=\frac{\mathrm{SI}+\mathrm{EI}+\mathrm{PI}+\mathrm{II}+\mathrm{AI}}{5}
$$

The original values of the indicators have been transformed to $0-1$ based on the vulnerability level, for the purpose of computing the indices. The values closer to 0 signify low vulnerability, whereas values closer to 1 denote high vulnerability. Each variable was further divided into classes depending on its characteristics: for example, nature of response was divided into two classes (yes or no response), three classes, four classes, and five classes, as required. With literature support, these classes were framed to demonstrate the degree of variation, as much as possible, in that particular variable. In dual classes, the values were 0 and 1 . The indicators with three classes were assigned the values $0.33,0.67$, and 1 ; for four classes, the values were $0.25,0.50,0.75$, and 1 ; and for five classes, the values were $0.2,0.4,0.6,0.8$, and 1 . Thus, the composite index for each component fell between 0 and 1 . Table 1 lists the indicators used for the different dimensions, the classes and values, and the empirical studies that have used these indicators.

\section{Results and Discussion}

Indices for each dimension were calculated using the methodology described in the previous section. Statistical tests were performed to understand the level of difference in each dimension. The results for each dimension are separately described, followed by an overall explanation of multidimensional vulnerability.

\subsection{Social Vulnerability}

The surveyed households in all three communities mostly had 5-10 members $(61 \%)$. Most of the households were nuclear families (87\%). About $22 \%$ of households included members who were suffering from a chronic illness or a physical/mental disability, or were pregnant, increasing vulnerability. A significant variation $\left(\chi^{2}=16.34\right.$, $p$ value $=0.03)$ was observed among the three communities with respect to education level of household head. Around $21 \%$ of household heads were illiterate, but most household heads were primary or secondary schooled. This lack of extended education increases vulnerability. It can critically endanger a household because of poor understanding of early warnings and emergency protocols. Most of the households (77\%) had been living in the hazardprone areas for over 10 years, making them aware of possible evacuation routes and safe areas in their community, reducing vulnerability. Around $79 \%$ of households had experienced floods, which would help them in foreseeing potential flood damages and mitigation measures. But in Rawalpindi many of the surveyed households had no past experience with floods, possibly because they were fresh migrants, which increased their vulnerability.

The social vulnerability index of households varied from 0.28 to 0.71 in Rawalpindi community, $0.22-0.62$ in Sialkot community, and $0.25-0.70$ in Muzaffargarh community, with an average value of $0.48,0.41$, and 0.44 in the three study sites, respectively. In terms of overall social vulnerability, a significant difference $(F=9.988$, $p$ value $=0.001)$ was observed among the three communities (Table 2). Around 21, 13, and 14\% of the surveyed households were highly vulnerable in Rawalpindi, Sialkot, and Muzaffargarh, respectively. Higher vulnerability in Rawalpindi community can be attributed to limited past experiences of households, and due to the fact that most families had relatively recently moved into houses constructed in the flood-prone area. With respect to overall social vulnerability, around $16 \%$ of the surveyed households were classified as highly vulnerable.

\subsection{Economic Vulnerability}

The dependency ratio (dependents to total household size) was relatively low in all three communities. However, a significant difference $\left(\chi^{2}=49.27, p\right.$ value $\left.=0.001\right)$ was observed in average monthly income among the three communities. Household heads were mostly the sole earning members of the household. In the Rawalpindi community, most of the households living in the floodprone areas were middle income, working as government employees, traders, or daily wage earners. In Sialkot community, most of the surveyed households belonged to 
Table 1 Indicators and transformed values for dimensions of vulnerability to urban flooding in Punjab Province, Pakistan

\begin{tabular}{|c|c|c|c|c|c|}
\hline $\begin{array}{l}\text { S. } \\
\text { No. }\end{array}$ & Indicators & Classes & $\begin{array}{l}\text { Transformed } \\
\text { values }\end{array}$ & Explanation & Empirical studies \\
\hline \multicolumn{6}{|c|}{ Social vulnerability } \\
\hline 1 & Household size (in number) & $\begin{array}{l}<5 \\
5-10 \\
>10\end{array}$ & $\begin{array}{l}0.33 \\
0.67 \\
1\end{array}$ & $\begin{array}{l}\text { The larger the household size, the higher } \\
\text { might be the vulnerability }\end{array}$ & $\begin{array}{l}\text { Cutter et al. (2003), } \\
\text { Birkmann et al. (2013) }\end{array}$ \\
\hline 2 & Family type & $\begin{array}{l}\text { Extended } \\
\text { Nuclear } \\
\text { Single }\end{array}$ & $\begin{array}{l}0.33 \\
0.67 \\
1\end{array}$ & $\begin{array}{l}\text { The extended family type will have more } \\
\text { strength in number, and have more } \\
\text { access to societal resources and } \\
\text { support }\end{array}$ & Rana and Routray (2016) \\
\hline 3 & Female-male ratio & $\begin{array}{l}<1 \\
1-2 \\
2-3 \\
3-4 \\
>4\end{array}$ & $\begin{array}{l}0.2 \\
0.4 \\
0.6 \\
0.8 \\
1\end{array}$ & $\begin{array}{l}\text { Males will be less vulnerable than } \\
\text { females due to their mobility and } \\
\text { physical strength }\end{array}$ & $\begin{array}{l}\text { Armaş (2012), Phung et al. } \\
\text { (2016) }\end{array}$ \\
\hline 4 & $\begin{array}{l}\text { Household that includes } \\
\text { family members with } \\
\text { chronic illness/pregnancy } \\
\text { or disability }\end{array}$ & $\begin{array}{l}0 \\
1 \\
2 \\
>2\end{array}$ & $\begin{array}{l}0 \\
0.33 \\
0.67 \\
1\end{array}$ & $\begin{array}{l}\text { Household with special needs will be } \\
\text { limited in its mobility in case of } \\
\text { emergency }\end{array}$ & $\begin{array}{l}\text { Hahn et al. (2009), Balica } \\
\quad \text { et al. (2012), Yoon (2012) }\end{array}$ \\
\hline 5 & $\begin{array}{l}\text { Household head's education } \\
\text { level }\end{array}$ & $\begin{array}{l}\text { No schooling } \\
\text { Primary } \\
\text { Middle } \\
\text { High } \\
\text { College/ } \\
\text { University }\end{array}$ & $\begin{array}{l}1 \\
0.8 \\
0.6 \\
0.4 \\
0.2\end{array}$ & $\begin{array}{l}\text { Low literacy will increase vulnerability } \\
\text { of household's access to information } \\
\text { and communication }\end{array}$ & $\begin{array}{l}\text { Hahn et al. (2009), Pandey } \\
\text { and Jha (2012), Armaş } \\
\text { (2012) }\end{array}$ \\
\hline 6 & $\begin{array}{l}\text { Household living in } \\
\text { community (in years) }\end{array}$ & $\begin{array}{l}>40 \\
30-40 \\
20-30 \\
10-20 \\
<10\end{array}$ & $\begin{array}{l}0.2 \\
0.4 \\
0.6 \\
0.8 \\
1\end{array}$ & $\begin{array}{l}\text { Household residing for shorter time may } \\
\text { not be aware of evacuation routes and } \\
\text { emergency protocols }\end{array}$ & Rana and Routray (2018) \\
\hline 7 & $\begin{array}{l}\text { Household having past } \\
\text { experiences with floods }\end{array}$ & $\begin{array}{l}\text { No } \\
\text { Yes }\end{array}$ & $\begin{array}{l}1 \\
0\end{array}$ & $\begin{array}{l}\text { People with previous encounters with } \\
\text { floods can foresee issues and problems } \\
\text { that could be faced }\end{array}$ & $\begin{array}{l}\text { Birkmann et al. (2013), Rana } \\
\text { and Routray (2018) }\end{array}$ \\
\hline Eco & omic vulnerability & & & & \\
\hline 1 & $\begin{array}{l}\text { Dependency ratio } \\
\text { (dependents to total } \\
\text { household size) }\end{array}$ & $\begin{array}{l}<0.25 \\
0.25-0.50 \\
0.50-0.75 \\
0.75-1 \\
>1\end{array}$ & $\begin{array}{l}0.2 \\
0.4 \\
0.6 \\
0.8 \\
1\end{array}$ & $\begin{array}{l}\text { Infants, children, and the elderly will be } \\
\text { more vulnerable than young persons } \\
\text { and adults, because of limited mobility } \\
\text { and dependency }\end{array}$ & $\begin{array}{l}\text { Pandey and Jha (2012), Gain } \\
\text { et al. (2015), Zhou et al. } \\
\text { (2015), Phung et al. (2016) }\end{array}$ \\
\hline 2 & $\begin{array}{l}\text { Average monthly } \\
\text { household's income (in } \\
\text { Pakistani rupees) }\end{array}$ & $\begin{array}{l}<10,000 \\
10,000-19,999 \\
20,000-39,999 \\
40,000-60,000 \\
>60,000\end{array}$ & $\begin{array}{l}1 \\
0.8 \\
0.6 \\
0.4 \\
0.2\end{array}$ & $\begin{array}{l}\text { Lower income results in higher } \\
\text { vulnerability }\end{array}$ & $\begin{array}{l}\text { Cutter et al. (2003), Balica } \\
\text { et al. (2009), Phung et al. } \\
\text { (2016) }\end{array}$ \\
\hline 3 & $\begin{array}{l}\text { Occupation of household } \\
\text { head }\end{array}$ & $\begin{array}{l}\text { Government } \\
\text { service } \\
\text { Trade and } \\
\text { Commerce } \\
\text { Agriculture } \\
\text { Daily wagers } \\
\text { Unemployed }\end{array}$ & $\begin{array}{l}0.2 \\
0.4 \\
0.6 \\
0.8 \\
1\end{array}$ & $\begin{array}{l}\text { Insecure sources of income will increase } \\
\text { vulnerability }\end{array}$ & $\begin{array}{l}\text { Armaş (2012), Pandey and } \\
\text { Jha (2012), Yoon (2012), } \\
\text { Mazumdar and Paul (2016), } \\
\text { Phung et al. (2016) }\end{array}$ \\
\hline
\end{tabular}


Table 1 continued

\begin{tabular}{|c|c|c|c|c|c|}
\hline $\begin{array}{l}\text { S. } \\
\text { No. }\end{array}$ & Indicators & Classes & $\begin{array}{l}\text { Transformed } \\
\text { values }\end{array}$ & Explanation & Empirical studies \\
\hline \multirow[t]{2}{*}{4} & \multirow{2}{*}{$\begin{array}{l}\text { Household that has taken out } \\
\text { a loan in the last } 10 \text { years }\end{array}$} & Yes & 1 & \multirow{2}{*}{$\begin{array}{l}\text { Household that has taken out a loan } \\
\text { within the last } 10 \text { years shows that it } \\
\text { could be economically challenged and } \\
\text { could be more vulnerable in case of } \\
\text { emergency }\end{array}$} & \multirow{2}{*}{$\begin{array}{l}\text { Hahn et al. (2009), Pandey } \\
\text { and Jha (2012) }\end{array}$} \\
\hline & & No & 0 & & \\
\hline \multirow[t]{2}{*}{5} & \multirow{2}{*}{$\begin{array}{l}\text { Household residing in rented } \\
\text { houses }\end{array}$} & Yes & 1 & \multirow{2}{*}{$\begin{array}{l}\text { Tenants on rent cannot repair, fortify } \\
\text { their buildings against floods }\end{array}$} & \multirow{2}{*}{$\begin{array}{l}\text { Cutter et al. (2003), Tate } \\
\text { (2012), Yoon (2012) }\end{array}$} \\
\hline & & No & 0 & & \\
\hline \multirow[t]{4}{*}{6} & \multirow{4}{*}{$\begin{array}{l}\text { Livelihood options of the } \\
\text { household }\end{array}$} & 0 & 1 & \multirow{4}{*}{$\begin{array}{l}\text { Multiple sources of livelihood will } \\
\text { decrease vulnerability because even if } \\
\text { one source is cut off, the household } \\
\text { can survive on another }\end{array}$} & \multirow[t]{4}{*}{ Hahn et al. (2009) } \\
\hline & & 1 & 0.75 & & \\
\hline & & 2 & 0.50 & & \\
\hline & & $>2$ & 0.25 & & \\
\hline \multirow[t]{4}{*}{7} & \multirow{4}{*}{$\begin{array}{l}\text { Number of earning members } \\
\text { in the household }\end{array}$} & 0 & 1 & \multirow{4}{*}{$\begin{array}{l}\text { Higher number of earning household } \\
\text { members can decrease vulnerability } \\
\text { because even if one income source is } \\
\text { cut off, the household can survive on } \\
\text { another }\end{array}$} & \multirow[t]{4}{*}{ Armaş (2012) } \\
\hline & & 1 & 0.75 & & \\
\hline & & 2 & 0.50 & & \\
\hline & & $>2$ & 0.25 & & \\
\hline \multirow[t]{2}{*}{8} & \multirow[t]{2}{*}{$\begin{array}{l}\text { Household with family } \\
\text { member employed outside } \\
\text { flood-prone area }\end{array}$} & No & 1 & \multirow{2}{*}{$\begin{array}{l}\text { Household with a family member } \\
\text { employed outside the flood-prone area } \\
\text { will sustain this family member's } \\
\text { income }\end{array}$} & \multirow[t]{2}{*}{$\begin{array}{l}\text { Hahn et al. (2009), Pandey } \\
\text { and Jha (2012) }\end{array}$} \\
\hline & & Yes & 0 & & \\
\hline \multirow[t]{2}{*}{9} & \multirow{2}{*}{$\begin{array}{l}\text { Household with land/house } \\
\text { outside the flood-prone } \\
\text { area }\end{array}$} & No & 1 & \multirow{2}{*}{$\begin{array}{l}\text { Household with additional assets outside } \\
\text { the flood-prone area can decrease } \\
\text { vulnerability, as such households can } \\
\text { settle outside the flooded area }\end{array}$} & \multirow[t]{2}{*}{ Wisner et al. (2004) } \\
\hline & & Yes & 0 & & \\
\hline \multirow[t]{2}{*}{10} & \multirow{2}{*}{$\begin{array}{l}\text { Household with means of } \\
\text { transportation }\end{array}$} & No & 1 & \multirow{2}{*}{$\begin{array}{l}\text { Household with no means of } \\
\text { transportation will be hindered in } \\
\text { evacuation }\end{array}$} & \multirow{2}{*}{$\begin{array}{l}\text { Tate (2012), Yoon (2012); } \\
\text { Mazumdar and Paul } \\
\text { (2016) }\end{array}$} \\
\hline & & Yes & 0 & & \\
\hline \multicolumn{6}{|c|}{ Physical/infrastructural vulnerability } \\
\hline 1 & Location of the house & $\begin{array}{l}\text { Between } \\
\text { Levee and } \\
\text { riverbank }\end{array}$ & 1 & $\begin{array}{l}\text { Low elevation and proximity to flood } \\
\text { hazard source will increase } \\
\text { vulnerability }\end{array}$ & $\begin{array}{l}\text { Balica et al. (2009), Thouret } \\
\text { et al. (2014) }\end{array}$ \\
\hline & & Floodplain & 0.67 & & \\
\hline & & Upland & 0.33 & & \\
\hline 2 & Building type & $\begin{array}{l}\text { Combined } \\
\text { (row } \\
\text { houses) }\end{array}$ & 1 & $\begin{array}{l}\text { Household residing in house with limited } \\
\text { open space and distance between } \\
\text { neighboring houses will increase }\end{array}$ & $\begin{array}{l}\text { Birkmann et al. (2013), } \\
\text { Thouret et al. (2014), Gain } \\
\text { et al. (2015), Papathoma- }\end{array}$ \\
\hline & & $\begin{array}{l}\text { Semidetached } \\
\quad \text { (common) }\end{array}$ & 0.67 & vulnerability & Köhle et al. (2017) \\
\hline & & $\begin{array}{l}\text { Detached } \\
\quad \text { (Bungalow) }\end{array}$ & 0.33 & & \\
\hline 3 & Building height(number of & Single & 1 & Household living in single-story & Birkmann et al. (2013), \\
\hline & stories) & Double & 0.67 & residence will increase vulnerability & Thouret et al. (2014), \\
\hline & & Triple & 0.33 & & (2017) \\
\hline 4 & Building age of household & $<10$ & 0.25 & Old houses will be structurally weaker & Birkmann et al. (2013), Gain \\
\hline & residence (in years) & $11-20$ & 0.50 & and make household more vulnerable & et al. (2015), Papathoma- \\
\hline & & $20-30$ & 0.75 & & t al. (2017) \\
\hline & & $>30$ & 1 & & \\
\hline 5 & $\begin{array}{l}\text { Construction materials of } \\
\text { household residence }\end{array}$ & $\begin{array}{l}\text { Katcha } \\
\text { (Adobe, } \\
\text { Mud) }\end{array}$ & 1 & $\begin{array}{l}\text { Type of materials used for construction } \\
\text { would affect structure. Katcha and } \\
\text { Pacca are local terminologies for }\end{array}$ & $\begin{array}{l}\text { Thouret et al. (2014), Gain } \\
\text { et al. (2015), Mazumdar } \\
\text { and Paul (2016), }\end{array}$ \\
\hline & & $\begin{array}{l}\text { Pacca } \text { (Brick, } \\
\text { Cement) }\end{array}$ & 0 & $\begin{array}{l}\text { describing strength of building } \\
\text { materials used }\end{array}$ & $\begin{array}{l}\text { Papathoma-Köhle et al. } \\
\text { (2017) }\end{array}$ \\
\hline
\end{tabular}


Table 1 continued

\begin{tabular}{|c|c|c|c|c|c|}
\hline $\begin{array}{l}\text { S. } \\
\text { No. }\end{array}$ & Indicators & Classes & $\begin{array}{l}\text { Transformed } \\
\text { values }\end{array}$ & Explanation & Empirical studies \\
\hline \multirow[t]{4}{*}{6} & \multirow{4}{*}{$\begin{array}{l}\text { Distance to nearest medical } \\
\text { facility (in } \mathrm{km} \text { ) }\end{array}$} & $<1$ & 0.25 & \multirow{4}{*}{$\begin{array}{l}\text { The longer the distance between nearest } \\
\text { health facility and residence, the } \\
\text { higher will be the vulnerability }\end{array}$} & \multirow{4}{*}{$\begin{array}{l}\text { Armaş (2012), Rana and } \\
\text { Routray (2016) }\end{array}$} \\
\hline & & $1-5$ & 0.50 & & \\
\hline & & $5-10$ & 0.75 & & \\
\hline & & $>10$ & 1 & & \\
\hline \multirow[t]{2}{*}{7} & \multirow{2}{*}{$\begin{array}{l}\text { Household access to } \\
\text { drinking water }\end{array}$} & Yes & 0 & \multirow{2}{*}{$\begin{array}{l}\text { Household with no access to safe } \\
\text { drinking water will be more vulnerable }\end{array}$} & \multirow{2}{*}{$\begin{array}{l}\text { Hahn et al. (2009), Zhou } \\
\text { et al. (2015), Mazumdar } \\
\text { and Paul (2016), Phung } \\
\text { et al. (2016) }\end{array}$} \\
\hline & & No & 1 & & \\
\hline \multirow[t]{2}{*}{8} & \multirow{2}{*}{$\begin{array}{l}\text { Household access to } \\
\text { improved sanitation }\end{array}$} & Yes & 0 & \multirow{2}{*}{$\begin{array}{l}\text { Household with no access to improved } \\
\text { sanitation will be more vulnerable }\end{array}$} & \multirow{2}{*}{$\begin{array}{l}\text { Balica et al. (2009), } \\
\text { Mazumdar and Paul } \\
\text { (2016), Phung et al. (2016) }\end{array}$} \\
\hline & & No & 1 & & \\
\hline \multirow[t]{2}{*}{9} & \multirow{2}{*}{$\begin{array}{l}\text { Household access to } \\
\text { electricity }\end{array}$} & Yes & 0 & \multirow{2}{*}{$\begin{array}{l}\text { Household with no access to electricity } \\
\text { will be more vulnerable }\end{array}$} & \multirow[t]{2}{*}{ Mazumdar and Paul (2016) } \\
\hline & & No & 1 & & \\
\hline \multirow[t]{2}{*}{10} & \multirow{2}{*}{$\begin{array}{l}\text { Household means of } \\
\text { communication (TV) }\end{array}$} & Yes & 0 & \multirow{8}{*}{$\begin{array}{l}\text { Household with no access to means of } \\
\text { communication will be more } \\
\text { vulnerable }\end{array}$} & \multirow{8}{*}{$\begin{array}{l}\text { Yoon (2012), Mazumdar and } \\
\text { Paul (2016) }\end{array}$} \\
\hline & & No & 1 & & \\
\hline \multirow[t]{2}{*}{11} & \multirow{2}{*}{$\begin{array}{l}\text { Household means of } \\
\text { communication (Radio) }\end{array}$} & Yes & 0 & & \\
\hline & & No & 1 & & \\
\hline \multirow[t]{2}{*}{12} & \multirow{2}{*}{$\begin{array}{l}\text { Household means of } \\
\text { communication } \\
\text { (Telephone) }\end{array}$} & Yes & 0 & & \\
\hline & & No & 1 & & \\
\hline \multirow[t]{2}{*}{13} & \multirow{2}{*}{$\begin{array}{l}\text { Household means of } \\
\text { communication (Mobile) }\end{array}$} & Yes & 0 & & \\
\hline & & No & 1 & & \\
\hline Instit & utional vulnerability & & & & \\
\hline 1 & Warning about last floods & Yes & 0 & Household that did not receive warning & Balica et al. (2009) \\
\hline & received by the household & No & 1 & $\begin{array}{l}\text { in last flood, indicates institution’s } \\
\text { inefficiency }\end{array}$ & \\
\hline 2 & Household's level of & Very high & 0.2 & Household that does not understand & Gain et al. (2015) \\
\hline & understanding national & High & 0.4 & national warning system, represents & \\
\hline & & Moderate & 0.6 & early warning & \\
\hline & & Low & 0.8 & & \\
\hline & & Very low & 1 & & \\
\hline 3 & Household's awareness & No & 1 & Lack of awareness of household shows & Balica et al. (2009) \\
\hline & $\begin{array}{l}\text { regarding emergency } \\
\text { shelter }\end{array}$ & Yes & 0 & incapacity of institutions & \\
\hline 4 & Household's awareness & No & 1 & & \\
\hline & $\begin{array}{l}\text { regarding evacuation } \\
\text { routes }\end{array}$ & Yes & 0 & & \\
\hline 5 & Availability and circulation & No & 1 & Unavailability and no circulation of & Bollin and Hidajat (2006) \\
\hline & $\begin{array}{l}\text { of emergency plans to } \\
\text { household }\end{array}$ & Yes & 0 & $\begin{array}{l}\text { emergency plans by institutions may } \\
\text { increase household vulnerability }\end{array}$ & \\
\hline 6 & Household's knowledge of & Very poor & 1 & Household not understanding local & Ho et al. (2008) \\
\hline & emergency protocols & Poor & 0.8 & authority's emergency procedures will & \\
\hline & regarding noods & Average & 0.6 & & \\
\hline & & Good & 0.4 & & \\
\hline & & Very good & 0.2 & & \\
\hline 7 & Frequency of public & 0 & 1 & Low number of participation in drills and & Bollin and Hidajat (2006) \\
\hline & awareness programs/drills & 1 & 0.67 & training shows inability of institution & \\
\hline & $\begin{array}{l}\text { attended by any } \\
\text { household member (in } \\
\text { number) }\end{array}$ & 2 & 0.33 & $\begin{array}{l}\text { regarding awareness campaigns and } \\
\text { drills }\end{array}$ & \\
\hline
\end{tabular}


Table 1 continued

\begin{tabular}{|c|c|c|c|c|c|}
\hline $\begin{array}{l}\text { S. } \\
\text { No. }\end{array}$ & Indicators & Classes & $\begin{array}{l}\text { Transformed } \\
\text { values }\end{array}$ & Explanation & Empirical studies \\
\hline \multicolumn{6}{|c|}{ Attitudinal vulnerability } \\
\hline 1 & $\begin{array}{l}\text { Household that has gone to } \\
\text { their local government for } \\
\text { assistance in the past } \\
12 \text { months }\end{array}$ & $\begin{array}{l}\text { No } \\
\text { Yes }\end{array}$ & $\begin{array}{l}1 \\
0\end{array}$ & $\begin{array}{l}\text { Household that distrusts local } \\
\text { governments might not follow their } \\
\text { protocols, and not seek their help. }\end{array}$ & $\begin{array}{l}\text { Hahn et al. (2009), Rana and } \\
\text { Routray (2016) }\end{array}$ \\
\hline 2 & $\begin{array}{l}\text { Community having land } \\
\text { use/zoning laws and } \\
\text { household following them }\end{array}$ & $\begin{array}{l}\text { No } \\
\text { Yes }\end{array}$ & $\begin{array}{l}1 \\
0\end{array}$ & $\begin{array}{l}\text { Household not following urban planning } \\
\text { regulations will be more vulnerable }\end{array}$ & $\begin{array}{l}\text { Balica et al. (2009), Rana and } \\
\quad \text { Routray (2016) }\end{array}$ \\
\hline 3 & $\begin{array}{l}\text { Community cooperation in } \\
\text { disaster response }\end{array}$ & $\begin{array}{l}\text { Very poor } \\
\text { Poor } \\
\text { Moderate } \\
\text { Good } \\
\text { Very good }\end{array}$ & $\begin{array}{l}1 \\
0.8 \\
0.6 \\
0.4 \\
0.2\end{array}$ & $\begin{array}{l}\text { Cooperation strength represents } \\
\text { community attitudes and social } \\
\text { networking towards helping each other } \\
\text { and coping with floods }\end{array}$ & Pandey and Jha (2012) \\
\hline 4 & $\begin{array}{l}\text { Household believing in } \\
\text { possibility of future } \\
\text { occurrence of floods }\end{array}$ & $\begin{array}{l}\text { Very low } \\
\text { Low } \\
\text { Moderate } \\
\text { High } \\
\text { Very high }\end{array}$ & $\begin{array}{l}1 \\
0.8 \\
0.6 \\
0.4 \\
0.2\end{array}$ & $\begin{array}{l}\text { Household not believing in flood } \\
\text { likelihood might be more vulnerable }\end{array}$ & $\begin{array}{l}\text { Ho et al. (2008), Miceli et al. } \\
\text { (2008) }\end{array}$ \\
\hline 5 & $\begin{array}{l}\text { Household feeling afraid of } \\
\text { flood }\end{array}$ & $\begin{array}{l}\text { Not afraid } \\
\text { Slightly afraid } \\
\text { Neutral } \\
\text { Afraid } \\
\text { Very much } \\
\quad \text { afraid }\end{array}$ & $\begin{array}{l}1 \\
0.8 \\
0.6 \\
0.4 \\
0.2\end{array}$ & $\begin{array}{l}\text { Household not feeling afraid of flood will } \\
\text { not seek preparedness measures } \\
\text { against future flooding, and might be } \\
\text { more vulnerable }\end{array}$ & $\begin{array}{l}\text { Ho et al. (2008), Miceli et al. } \\
\text { (2008), Terpstra and } \\
\text { Gutteling (2008) }\end{array}$ \\
\hline 6 & $\begin{array}{l}\text { Household fearing potential } \\
\text { destruction of their } \\
\text { houses/assets }\end{array}$ & $\begin{array}{l}\text { Very low } \\
\text { Low } \\
\text { Moderate } \\
\text { High } \\
\text { Very high }\end{array}$ & $\begin{array}{l}1 \\
0.8 \\
0.6 \\
0.4 \\
0.2\end{array}$ & $\begin{array}{l}\text { Household fearing potential destruction } \\
\text { of their houses might be less } \\
\text { vulnerable }\end{array}$ & $\begin{array}{l}\text { Miceli et al. (2008), Terpstra } \\
\text { and Gutteling (2008) }\end{array}$ \\
\hline 7 & $\begin{array}{l}\text { Household's level of trust } \\
\text { and following government } \\
\text { disaster risk reduction } \\
\text { programs and policies }\end{array}$ & $\begin{array}{l}\text { Very low } \\
\text { Low } \\
\text { Moderate } \\
\text { High } \\
\text { Very high }\end{array}$ & $\begin{array}{l}1 \\
0.8 \\
0.6 \\
0.4 \\
0.2\end{array}$ & $\begin{array}{l}\text { Household not agreeing with government } \\
\text { initiatives will not follow them and } \\
\text { increase household vulnerability }\end{array}$ & Rana and Routray (2016) \\
\hline
\end{tabular}

${ }^{\mathrm{a} U S D} 1=122.50$ Pakistani rupees (August 2018)

middle to high income groups, and most of them were involved in industrial jobs and private businesses.

In Muzaffargarh community, most of the surveyed households were poor to middle income and worked in the agricultural sector, and around $12 \%$ of the household members were unemployed, making those households highly vulnerable. Almost 33\% of the households had taken out a loan, and around $20 \%$ lived in rented houses. Around $7 \%$ of the households had a member working outside the flood-prone community, which could decrease the vulnerability of these households. Significantly, $82 \%$ of the households had no other asset (land/house outside flood-prone area), making them economically challenged.
The economic vulnerability index of households varied from 0.28 to 0.77 in Rawalpindi community, $0.35-0.77$ in Sialkot community, and 0.48-0.89 in Muzaffargarh community. The average value was 0.58 in Rawalpindi, 0.60 in Sialkot, and 0.64 in Muzaffargarh. In terms of overall economic vulnerability, a significant difference $(F=8.309$, $p$ value $=0.001)$ was also observed among the three communities (Table 3). In the Rawalpindi community, around $23 \%$ of the surveyed households were economically vulnerable, while around $24 \%$ and $9 \%$ of the households were vulnerable in Sialkot and Muzaffargarh, respectively. This difference can be attributed to the fact that the number of earning members and house/land ownership was higher 
Table 2 Social vulnerability to urban flooding in Dhok Ratta, Hajipura, and Khangarh City, Punjab Province, Pakistan (HHs = Households; $n=210)$

\begin{tabular}{|c|c|c|c|c|c|c|c|c|}
\hline City & Classes & Very low & Low & Moderate & High & Total & Descriptive statistics & ANOVA \\
\hline \multirow[t]{4}{*}{ Dhok Ratta, Rawalpindi } & Range & $<0.39$ & $0.39-0.49$ & $0.49-0.60$ & $>0.60$ & & $\operatorname{Min}=0.286$ & $F=9.988$ \\
\hline & No. of HHs & 18 & 21 & 16 & 15 & 70 & $\operatorname{Max}=0.714$ & $\mathrm{df}=2$ \\
\hline & $\%$ & 25.7 & 30.0 & 22.9 & 21.4 & 100 & Mean $=0.489$ & $p$ value $=0.001$ \\
\hline & & & & & & & $\mathrm{SD}=0.111$ & \\
\hline \multirow[t]{4}{*}{ Hajipura, Sialkot } & Range & $<0.32$ & $0.32-0.42$ & $0.42-0.52$ & $>0.52$ & & Min $=0.229$ & \\
\hline & No. of HHs & 7 & 32 & 22 & 9 & 70 & $\operatorname{Max}=0.622$ & \\
\hline & $\%$ & 10 & 45.7 & 31.4 & 12.9 & 100 & Mean $=0.415$ & \\
\hline & & & & & & & $\mathrm{SD}=0.078$ & \\
\hline \multirow[t]{4}{*}{ Khangarh City, Muzaffargarh } & Range & $<0.36$ & $0.36-0.48$ & $0.48-0.59$ & $>0.59$ & & Min $=0.257$ & \\
\hline & No. of $\mathrm{HHs}$ & 17 & 32 & 11 & 10 & 70 & $\operatorname{Max}=0.706$ & \\
\hline & $\%$ & 24.3 & 45.7 & 15.7 & 14.3 & 100 & Mean $=0.442$ & \\
\hline & & & & & & & $\mathrm{SD}=0.107$ & \\
\hline \multirow[t]{2}{*}{ Total } & No. of HHs & 42 & 85 & 49 & 34 & 210 & & \\
\hline & $\%$ & 20.00 & 40.47 & 23.33 & 16.19 & 100 & & \\
\hline
\end{tabular}

Table 3 Economic vulnerability to urban flooding in Dhok Ratta, Hajipura, and Khangarh City, Punjab Province, Pakistan (HHs = Households; $n=210)$

\begin{tabular}{|c|c|c|c|c|c|c|c|c|}
\hline City & Classes & Very Low & Low & Moderate & High & Total & Descriptive Statistics & ANOVA \\
\hline Dhok Ratta, Rawalpindi & $\begin{array}{l}\text { Range } \\
\text { No. of HHs } \\
\%\end{array}$ & $\begin{array}{l}<0.40 \\
2 \\
2.9\end{array}$ & $\begin{array}{l}0.40-0.52 \\
8 \\
11.4\end{array}$ & $\begin{array}{l}0.52-0.64 \\
44 \\
62.9\end{array}$ & $\begin{array}{l}>0.64 \\
16 \\
22.9\end{array}$ & $\begin{array}{l}70 \\
100\end{array}$ & $\begin{array}{l}\text { Min }=0.280 \\
\operatorname{Max}=0.770 \\
\text { Mean }=0.586 \\
\mathrm{SD}=0.086\end{array}$ & $\begin{array}{l}F=8.309 \\
\mathrm{df}=2 \\
p \text { value }=0.001\end{array}$ \\
\hline Hajipura, Sialkot & $\begin{array}{l}\text { Range } \\
\text { No. of HHs } \\
\%\end{array}$ & $\begin{array}{l}<0.45 \\
8 \\
11.4\end{array}$ & $\begin{array}{l}0.45-0.56 \\
10 \\
14.3\end{array}$ & $\begin{array}{l}0.56-0.66 \\
35 \\
50.0\end{array}$ & $\begin{array}{l}>0.66 \\
17 \\
24.3\end{array}$ & $\begin{array}{l}70 \\
100\end{array}$ & $\begin{array}{l}\operatorname{Min}=0.350 \\
\operatorname{Max}=0.770 \\
\text { Mean }=0.600 \\
S D=0.094\end{array}$ & \\
\hline Khangarh City, Muzaffargarh & $\begin{array}{l}\text { Range } \\
\text { No. of HHs } \\
\%\end{array}$ & $\begin{array}{l}<0.58 \\
23 \\
32.9\end{array}$ & $\begin{array}{l}0.58-0.68 \\
19 \\
27.1\end{array}$ & $\begin{array}{l}0.68-0.78 \\
22 \\
31.4\end{array}$ & $\begin{array}{l}>0.78 \\
6 \\
8.6\end{array}$ & $\begin{array}{l}70 \\
100\end{array}$ & $\begin{array}{l}\operatorname{Min}=0.480 \\
\operatorname{Max}=0.890 \\
\text { Mean }=0.648 \\
S D=0.100\end{array}$ & \\
\hline Total & $\begin{array}{l}\text { No. of } \mathrm{HHs} \\
\%\end{array}$ & $\begin{array}{l}33 \\
15.71\end{array}$ & $\begin{array}{l}37 \\
17.61\end{array}$ & $\begin{array}{l}101 \\
48.09\end{array}$ & $\begin{array}{l}39 \\
18.57\end{array}$ & $\begin{array}{l}210 \\
100\end{array}$ & & \\
\hline
\end{tabular}

in Muzaffargarh community. Overall, with respect to economic vulnerability, around $19 \%$ of the surveyed households were highly vulnerable.

\subsection{Physical/Infrastructural Vulnerability}

Almost half of the surveyed households lived in highly vulnerable floodplains, and some had even built houses inside levees and embankments. These houses were built illegally inside the floodplains when the floods had receded last time. Generally, most of the houses were semidetached, single story, and built almost 20 years ago. Only a few households were living in adobe houses. In terms of infrastructural services, almost every household had access to electricity, radio, a landline, and a mobile, which can decrease vulnerability. But provision of clean drinking water and improved sanitation varied among communities, which can increase the vulnerabilities of already exposed communities.

The physical vulnerability index of households varied from 0.17 to 0.46 in Rawalpindi community, 0.18-0.30 in Sialkot community, and $0.18-0.80$ in Muzaffargarh 
Table 4 Physical and infrastructural vulnerability to urban flooding in Dhok Ratta, Hajipura, and Khangarh City, Punjab Province, Pakistan (HHs = Households; $n=210$ )

\begin{tabular}{|c|c|c|c|c|c|c|c|c|}
\hline City & Classes & Very low & Low & Moderate & High & Total & Descriptive statistics & ANOVA \\
\hline \multirow[t]{4}{*}{ Dhok Ratta, Rawalpindi } & Range & $<0.25$ & $0.25-0.32$ & $0.32-0.39$ & $>0.39$ & & $\operatorname{Min}=0.179$ & $F=9.714$ \\
\hline & No. of HHs & 24 & 41 & 2 & 3 & 70 & $\operatorname{Max}=0.468$ & $\mathrm{df}=2$ \\
\hline & $\%$ & 34.3 & 58.6 & 2.9 & 4.3 & 100 & Mean $=0.271$ & $p$ value $=0.001$ \\
\hline & & & & & & & $\mathrm{SD}=0.050$ & \\
\hline \multirow[t]{4}{*}{ Hajipura, Sialkot } & Range & $<0.21$ & $0.21-0.24$ & $0.24-0.27$ & $>0.27$ & & $\operatorname{Min}=0.186$ & \\
\hline & No. of $\mathrm{HHs}$ & 17 & 24 & 21 & 8 & 70 & $\operatorname{Max}=0.308$ & \\
\hline & $\%$ & 24.3 & 34.3 & 30.0 & 11.4 & 100 & Mean $=0.238$ & \\
\hline & & & & & & & $\mathrm{SD}=0.026$ & \\
\hline \multirow[t]{4}{*}{ Khangarh City, Muzaffargarh } & Range & $<0.34$ & $0.34-0.49$ & $0.49-0.64$ & $>0.64$ & & Min $=0.186$ & \\
\hline & No. of $\mathrm{HHs}$ & 59 & 6 & 1 & 4 & 70 & $\operatorname{Max}=0.802$ & \\
\hline & $\%$ & 84.3 & 8.6 & 1.4 & 5.7 & 100 & Mean $=0.296$ & \\
\hline & & & & & & & $\mathrm{SD}=0.121$ & \\
\hline \multirow[t]{2}{*}{ Total } & No. of HHs & 100 & 70 & 24 & 15 & 210 & & \\
\hline & $\%$ & 47.61 & 33.80 & 11.42 & 7.14 & 100 & & \\
\hline
\end{tabular}

community. The average value was 0.27 in Rawalpindi, 0.23 in Sialkot, and 0.29 in Muzaffargarh. Regarding overall physical vulnerability, a significant difference $(F=9.714, p$ value $=0.001)$ was also observed among the three communities (Table 4). In the Rawalpindi community around $4 \%$ of the surveyed households were deemed vulnerable, while around $11 \%$ and $6 \%$ of the households were vulnerable in Sialkot and Muzaffargarh, respectively. Households of Rawalpindi community belonged to a metropolitan region, and they enjoyed better access to physical and infrastructural amenities over other two study sites. Overall, with respect to physical vulnerability, around $7 \%$ of the surveyed households were highly vulnerable.

\subsection{Institutional Vulnerability}

Institutional vulnerability included reach and efficiency of early warning systems, risk communication, and emergency planning by institutions. A significant difference $\left(\chi^{2}=25.507, p\right.$ value $\left.=0.001\right)$ was observed regarding the reach of early warning systems. More than half of the households $(51 \%)$ in the study areas did not receive any kind of warning the last time a flood occurred in the community. This inefficiency can be attributed to the nonexistence of district management authority, and no local agency was officially delegated with this responsibility. Moreover, respondents stressed that without informing nearby settlements, local institutions often break embankments to save critical infrastructure. Around $72 \%$ and $73 \%$ of the households were unaware of the location of emergency shelters and evacuation routes, respectively. Around $95 \%$ of the households did not have access to emergency plans, increasing their vulnerability. Almost $96 \%$ of the household members had never attended any kind of awareness program or mock drill to cope with flooding. Households asserted that local administrations had not helped them prepare for flood hazards and mitigation.

The institutional vulnerability index of households varied from 0.28 to 1.0 in Rawalpindi community, 0.31-0.94 in Sialkot community, and 0.13-1.0 in Muzaffargarh community. The average value was 0.85 in Rawalpindi, 0.63 in Sialkot, and 0.76 in Muzaffargarh. In terms of overall institutional vulnerability, a significant difference $(F=27.970, p$ value $=0.001)$ was observed between the three study areas (Table 5). The highest vulnerability was observed in the Rawalpindi community where $67 \%$ of the surveyed households were highly vulnerable, while around $24 \%$ and $44 \%$ of the surveyed households were highly vulnerable in Sialkot and Muzaffargarh, respectively. In Rawalpindi, institutions were not actively disseminating emergency plans and protocols, hence raising vulnerability of the Rawalpindi metropolitan.

\subsection{Attitudinal Vulnerability}

Around $94 \%$ of the households had never approached local institutions to seek help or advice regarding flood preparedness. Respondents indicated that they distrusted the local institutions, probably because of the institutions' failure to disseminate early warnings. Lack of communication between exposed households and local institutions can also be attributed to illegally built houses in the floodplains, restricting households from seeking help 
Table 5 Institutional vulnerability to urban flooding in Dhok Ratta, Hajipura, and Khangarh City, Punjab Province, Pakistan (HHs = Households; $n=210$ )

\begin{tabular}{|c|c|c|c|c|c|c|c|c|}
\hline City & Classes & Very low & Low & Moderate & High & Total & Descriptive statistics & ANOVA \\
\hline \multirow[t]{4}{*}{ Dhok Ratta, Rawalpindi } & Range & $<0.46$ & $0.46-0.64$ & $0.64-0.82$ & $>0.82$ & & $\operatorname{Min}=0.286$ & $F=27.970 \mathrm{df}=2$ \\
\hline & No. of HHs & 3 & 5 & 15 & 47 & 70 & $\operatorname{Max}=1.000$ & $p$ value $=0.001$ \\
\hline & $\%$ & 4.3 & 7.1 & 21.4 & 67.1 & 100 & Mean $=0.847$ & \\
\hline & & & & & & & $\mathrm{SD}=0.156$ & \\
\hline \multirow[t]{4}{*}{ Hajipura, Sialkot } & Range & $<0.47$ & $0.47-0.62$ & $0.62-0.78$ & $>0.78$ & & $\operatorname{Min}=0.314$ & \\
\hline & No. of HHs & 30 & 8 & 15 & 17 & 70 & $\operatorname{Max}=0.943$ & \\
\hline & $\%$ & 42.9 & 11.4 & 21.4 & 24.3 & 100 & Mean $=0.634$ & \\
\hline & & & & & & & $\mathrm{SD}=0.187$ & \\
\hline \multirow[t]{4}{*}{ Khangarh City, Muzaffargarh } & Range & $<0.34$ & $0.34-0.56$ & $0.56-0.78$ & $>0.78$ & & $\operatorname{Min}=0.133$ & \\
\hline & No. of HHs & 1 & 6 & 32 & 31 & 70 & $\operatorname{Max}=1.000$ & \\
\hline & $\%$ & 1.4 & 8.6 & 45.7 & 44.3 & 100 & Mean $=0.761$ & \\
\hline & & & & & & & $\mathrm{SD}=0.165$ & \\
\hline \multirow[t]{2}{*}{ Total } & No. of HHs & 34 & 19 & 62 & 95 & 210 & & \\
\hline & $\%$ & 16.19 & 9.04 & 29.52 & 45.23 & 100 & & \\
\hline
\end{tabular}

officially, because local institutions might start litigation measures against them. Around $96 \%$ of the respondents believed that people in their community did not follow building regulations and zoning laws. Interestingly, around $86 \%$ of the households did not believe in community cooperation when floods strike, highlighting the underutilization of social capital. Respondents were of the opinion that everyone looks after themselves, and no one pays much attention to the people around them in disaster settings. Despite the classification of urban centers exposed to high flood risk by the National Disaster Management Authority (NDMA), only about $20 \%$ of the surveyed households believed that there is the possibility of future flood occurrence. Only a meagre $6 \%$ of households trusted government initiatives for disaster risk reduction and climate change adaptation. This indicates the poor perceptions and fatalistic attitudes of households that are hindering them from pursuing precautionary and mitigation measures against flood hazards.

The attitudinal vulnerability index value of households varied from 0.54 to 0.91 in Rawalpindi community, 0.51-0.94 in Sialkot community, and 0.48-0.82 in Muzaffargarh community with an average value of 0.79 , 0.75 , and 0.68 in the three cities, respectively. Regarding overall attitudinal vulnerability, a significant difference $(F=36.577, p$ value $=0.001)$ was observed among the

Table 6 Attitudinal vulnerability to urban flooding in Dhok Ratta, Hajipura, and Khangarh City, Punjab Province, Pakistan (HHs = Households; $n=210)$

\begin{tabular}{|c|c|c|c|c|c|c|c|c|}
\hline City & Classes & Very low & Low & Moderate & High & Total & Descriptive statistics & ANOVA \\
\hline \multirow[t]{4}{*}{ Dhok Ratta, Rawalpindi } & Range & $<0.63$ & $0.63-0.72$ & $0.72-0.82$ & $>0.82$ & & $\operatorname{Min}=0.543$ & $F=36.577$ \\
\hline & No. of HHs & 4 & 8 & 23 & 35 & 70 & $\operatorname{Max}=0.914$ & $\mathrm{df}=2$ \\
\hline & $\%$ & 5.7 & 11.4 & 32.9 & 50 & 100 & Mean $=0.794$ & $p$ value $=0.001$ \\
\hline & & & & & & & $\mathrm{SD}=0.080$ & \\
\hline \multirow[t]{4}{*}{ Hajipura, Sialkot } & Range & $<0.62$ & $0.62-0.72$ & $0.72-0.83$ & $>0.83$ & & $\operatorname{Min}=0.514$ & \\
\hline & No. of HHs & 3 & 13 & 52 & 2 & 70 & $\operatorname{Max}=0.943$ & \\
\hline & $\%$ & 4.3 & 18.6 & 74.3 & 2.9 & 100 & Mean $=0.759$ & \\
\hline & & & & & & & $\mathrm{SD}=0.069$ & \\
\hline \multirow[t]{4}{*}{ Khangarh City, Muzaffargarh } & Range & $<0.57$ & $0.57-0.65$ & $0.65-0.74$ & $>0.74$ & & $\operatorname{Min}=0.486$ & \\
\hline & No. of HHs & 6 & 11 & 32 & 21 & 70 & $\operatorname{Max}=0.829$ & \\
\hline & $\%$ & 8.6 & 15.7 & 45.7 & 30.0 & 100 & Mean $=0.685$ & \\
\hline & & & & & & & $\mathrm{SD}=0.080$ & \\
\hline \multirow[t]{2}{*}{ Total } & No. of HHs & 13 & 32 & 107 & 58 & 210 & & \\
\hline & $\%$ & 6.1 & 15.2 & 50.1 & 27.6 & 100 & & \\
\hline
\end{tabular}


Table 7 Multidimensional vulnerability to urban flooding in Dhok Ratta, Hajipura, and Khangarh City, Punjab Province, Pakistan $(\mathrm{HHs}=$ Households; $n=210)$

\begin{tabular}{|c|c|c|c|c|c|c|c|c|}
\hline City & Classes & Very low & Low & Moderate & High & Total & Descriptive statistics & ANOVA \\
\hline \multirow[t]{4}{*}{ Dhok Ratta, Rawalpindi } & Range & $<0.51$ & $0.51-0.55$ & $0.55-0.60$ & $>0.60$ & & $\operatorname{Min}=0.474$ & $F=32.726$ \\
\hline & No. of HHs & 14 & 24 & 24 & 8 & 70 & $\operatorname{Max}=0.645$ & $\mathrm{df}=2$ \\
\hline & $\%$ & 20.3 & 34.3 & 34.3 & 11.4 & 100 & Mean $=0.553$ & $p$ value $=0.001$ \\
\hline & & & & & & & $\mathrm{SD}=0.040$ & \\
\hline \multirow[t]{4}{*}{ Hajipura, Sialkot } & Range & $<0.46$ & $0.46-0.50$ & $0.50-0.54$ & $>0.54$ & & $\operatorname{Min}=0.419$ & \\
\hline & No. of HHs & 9 & 37 & 18 & 6 & 70 & $\operatorname{Max}=0.591$ & \\
\hline & $\%$ & 12.9 & 52.9 & 25.7 & 8.6 & 100 & Mean $=0.495$ & \\
\hline & & & & & & & $\mathrm{SD}=0.035$ & \\
\hline \multirow[t]{4}{*}{ Khangarh City, Muzaffargarh } & Range & $<0.44$ & $0.44-0.51$ & $0.51-0.59$ & $>0.59$ & & $\operatorname{Min}=0.368$ & \\
\hline & No. of $\mathrm{HHs}$ & 2 & 23 & 37 & 8 & 70 & $\operatorname{Max}=0.669$ & \\
\hline & $\%$ & 2.9 & 32.9 & 52.9 & 11.4 & 100 & Mean $=0.536$ & \\
\hline & & & & & & & $\mathrm{SD}=0.053$ & \\
\hline \multirow[t]{2}{*}{ Total } & No. of HHs & 25 & 84 & 79 & 22 & 210 & & \\
\hline & $\%$ & 11.90 & 40.00 & 37.62 & 10.47 & 100 & & \\
\hline
\end{tabular}

three communities (Table 6). In the Rawalpindi community, around $50 \%$ of the surveyed households were deemed vulnerable. Around $2 \%$ and $30 \%$ of the households were vulnerable in Sialkot and Muzaffargarh, respectively. Newly migrated households in Rawalpindi community have not faced floods, thus their risk perception was poor, as compared to other two study sites. Overall, with respect to attitudinal vulnerability, around $28 \%$ of the surveyed households were highly vulnerable.

\subsection{Multidimensional Vulnerability}

The results in the previous sections highlight the five dimensions of vulnerability and emphasize the myriad factors that affect these dimensions. Different dynamics influence the flood vulnerability in the three urban centers. Muzaffargarh is prone to riverine floods, while Sialkot and Rawalpindi are prone to flash and pluvial floods, a marked difference in flood hazard sources. The degree of overall multidimensional flood vulnerability significantly $(F=32.726, p$ value $=0.001)$ varied among the study sites in the three urban centers (Table 7). In Rawalpindi and Muzaffargarh, about $12 \%$ of the surveyed households were highly vulnerable, while $9 \%$ of households in Sialkot were highly vulnerable. Overall, around $10 \%$ of households in the three surveyed urban communities were deemed highly vulnerable.

Figure 2 reveals interesting insights into each dimension of vulnerability, through average index values. Slight variations were observed in social, economic, and physical/ infrastructural vulnerability among the three study sites. The variation was much more pronounced in terms of attitudinal and institutional vulnerability. Except in the economic vulnerability dimension, the surveyed households of the Muzaffargarh study site were most vulnerable in all other dimensions of vulnerability. The surveyed households of the Sialkot study site were least vulnerable in all dimensions except in the attitudinal vulnerability dimension. Attitudinal and institutional vulnerability were much higher than other vulnerability dimensions, signifying the poor risk perceptions of residents and distrust among the communities and the disaster management institutions. Overall, the average multidimensional vulnerability was more or less the same for all three urban communities. These findings show that there is a strong need to launch awareness campaigns and design risk communication strategies to enhance the flood risk perceptions of the communities and engage the local institutions with the communities to implement disaster risk reduction strategies effectively.

\section{Conclusion}

This study argues that vulnerability to urban flooding or any other hazard must not be treated as a single entity, but rather as a composition of social, economic, physical/infrastructural, institutional, and attitudinal factors, and proposes a multidimensional model to measure vulnerability. The study provides a clear and useful methodology, which can comprehensively measure the dimensional and aggregate degree of vulnerability. It is a simple, easy, and quickto-use method, and can be employed by disaster risk experts regardless of professional background. The model 
Fig. 2 Multidimensional vulnerability to urban flooding in Dhok Ratta (Rawalpindi), Hajipura (Sialkot), and Khangarh City (Muzaffargarh), Punjab Province, Pakistan

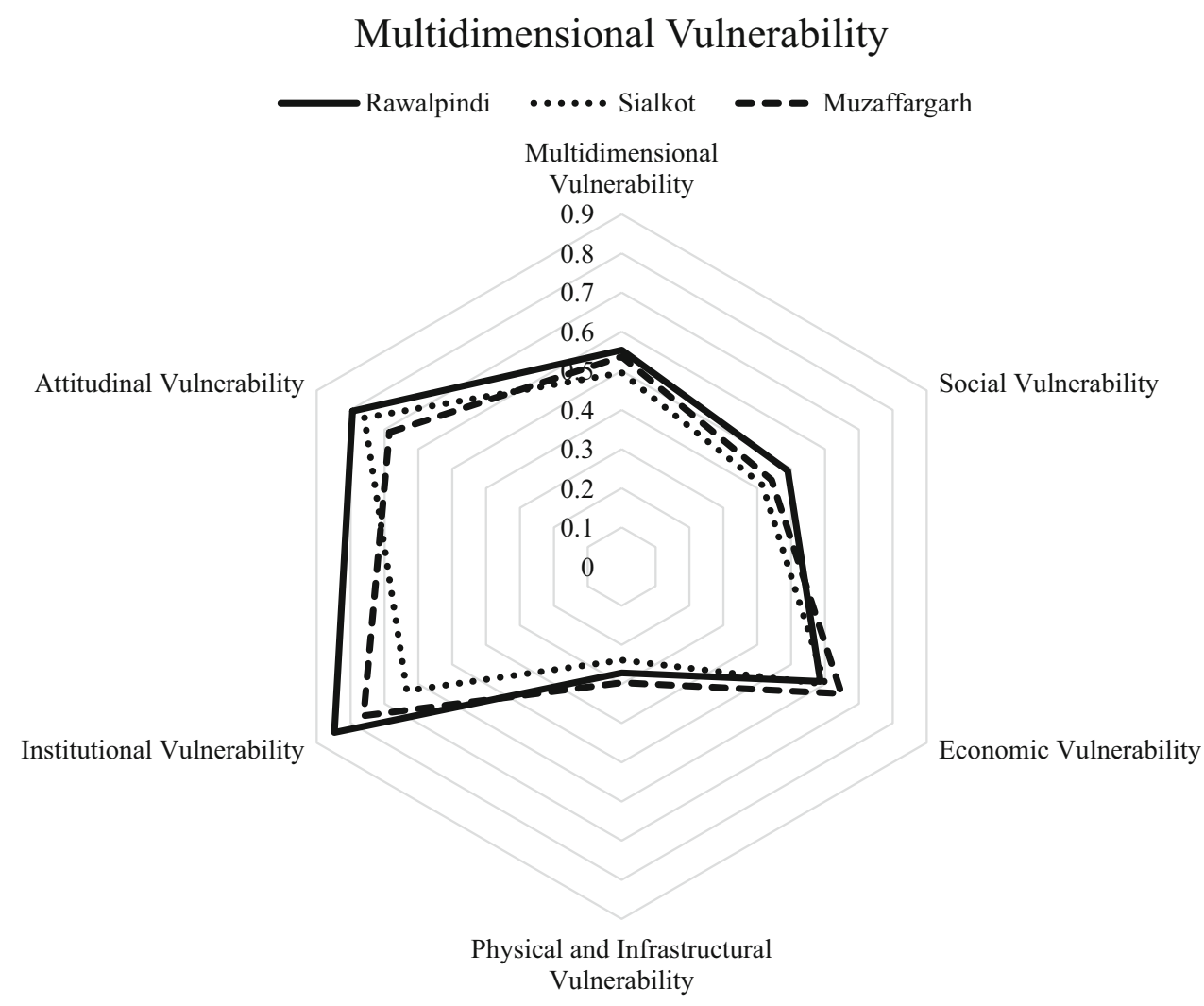

not only helps in identifying the most vulnerable populations, but also the exact dimensions that are making them vulnerable. The index value for each indicator can help in identifying the underlying factors responsible for an increase in vulnerability and can assist in highlighting a relevant course of action for disaster management. This can support local institutions in the formulation of emergency and recovery plans, awareness campaigns, and disaster risk reduction strategies, appropriate to each vulnerability dimension. Using adjusted sampling design, this flexible and robust methodology can be used at various spatial scales, urban or rural, and can also be used in the context of other natural hazards by streamlining disaster specific indicators. Depending on data availability, more indicators can be included or excluded in the vulnerability dimensions, for better reflection of local needs. This methodology can further be improved by incorporating statistical models for assigning weights, which may differ at different spatial scales. Differing levels of hazard and exposure must not be considered inconsequential, which might increase or decrease disaster risk as a whole.

This study further provides insights into the proposed methodology through its application in three flood-prone urban communities in Pakistan. The national development plans of Pakistan entail sector-wise development, into which various components of vulnerability fit perfectly. This study has found significant variations in all dimensions of vulnerability, especially institutional and attitudinal vulnerability. The results reveal that all three communities have fatalistic attitudes and poor risk perception. Institutions have been unable to provide appropriate awareness, training, and drills, which has amplified the vulnerabilities of the already exposed communities. District disaster management authorities are still absent at the ground level, and local institutions are managing floods on an ad hoc basis. This research will be instrumental for institutions and local governments concerned with disaster management and developing future strategies for disaster risk reduction, especially for flood-prone urban areas.

Open Access This article is distributed under the terms of the Creative Commons Attribution 4.0 International License (http://crea tivecommons.org/licenses/by/4.0/), which permits unrestricted use, distribution, and reproduction in any medium, provided you give appropriate credit to the original author(s) and the source, provide a link to the Creative Commons license, and indicate if changes were made.

\section{References}

Adger, W.N. 2006. Vulnerability. Global Environmental Change 16(3): 268-281.

Adger, W.N., N. Brooks, G. Bentham, M. Agnew, and S. Eriksen. 2004. New indicators of vulnerability and adaptive capacity. Norwich: University of East Anglia. http://dcms.lwec.ulcc.ac.uk/ sites/default/files/it1_11.pdf. Accessed 27 May 2017. 
Armaş, I. 2012. Multi-criteria vulnerability analysis to earthquake hazard of Bucharest, Romania. Natural Hazards 63(2): $1129-1156$.

Balica, S.F., N. Douben, and N.G. Wright. 2009. Flood vulnerability indices at varying spatial scales. Water Science \& Technology 60(10): 2571-2580.

Balica, S.F., N.G. Wright, and F. van der Meulen. 2012. A flood vulnerability index for coastal cities and its use in assessing climate change impacts. Natural Hazards 64(1): 73-105.

Birkmann, J. 2006. Measuring vulnerability to promote disasterresilient societies: Conceptual frameworks and definitions. In Measuring vulnerability to natural hazards: Towards disaster resilient societies, ed. J. Birkmann, 9-54. Tokyo: United Nations University-Institute for Environment and Human Security (UNU-EHS).

Birkmann, J., O.D. Cardona, M.L. Carreño, A.H. Barbat, M. Pelling, S. Schneiderbauer, S. Kienberger, M. Keiler, D. Alexander, P. Zeil, T. Welle. 2013. Framing vulnerability, risk and societal responses: The MOVE framework. Natural Hazards 67(2): 193-211.

Bogardi, J., and J. Birkmann. 2004. Vulnerability assessment: The first step towards sustainable risk reduction. In Disasters and society-from hazard assessment to risk reduction, ed. D. Malzahn, and T. Plapp, 75-82. Berlin: Logos Verlag.

Bohle, H.G. 2001. Vulnerability and criticality: Perspectives from social geography. IHDP Update, Newsletter of the International Human Dimensions Programme on Global Environmental Change 2: Article 1.

Bollin, C., and R. Hidajat. 2006. Community-based risk index: Pilot implementation in Indonesia. In Measuring vulnerability to natural hazards: Towards disaster resilient societies, ed. J. Birkmann, 271-289. Tokyo: United Nations University Institute for Environment and Human Security (UNU-EHS).

Briguglio, L. 1995. Small island developing states and their economic vulnerabilities. World Development 23(9): 1615-1632.

Cochran, W.G. 1977. Sampling techniques, 3rd edn. New York: John Wiley and Sons.

Cutter, S.L., B.J. Boruff, and W.L. Shirley. 2003. Social vulnerability to environmental hazards. Social Science Quarterly 84(2): 242-261.

Cutter, S.L., J.T. Mitchell, and M.S. Scott. 2000. Revealing the vulnerability of people and places: A case study of Georgetown county, South Carolina. Annals of the Association of American Geographers 90(4): 713-737.

Federal Flood Commission. 2012. Annual flood report 2012. Islamabad, Pakistan: Federal Flood Commission.

Fuchs, S., J. Birkmann, and T. Glade. 2012. Vulnerability assessment in natural hazard and risk analysis: Current approaches and future challenges. Natural Hazards 64(3): 1969-1975.

Gain, A.K., V. Mojtahed, C. Biscaro, S. Balbi, and C. Giupponi. 2015. An integrated approach of flood risk assessment in the eastern part of Dhaka city. Natural Hazards 79(3): 1-32.

Hahn, M.B., A.M. Riederer, and S.O. Foster. 2009. The livelihood vulnerability index: A pragmatic approach to assessing risks from climate variability and change-A case study in Mozambique. Global Environmental Change 19(1): 74-88.

Hallegatte, S., C. Green, R.J. Nicholls, and J. Corfee-Morlot. 2013. Future flood losses in major coastal cities. Nature Climate Change 3(9): 802-806

Ho, M., D. Shaw, S.Lin, and Y. Chiu. 2008. How do disaster characteristics influence risk perception? Risk Analysis 28(3): 635-643.

IPCC (Intergovernmental Panel on Climate Change). 2012. Managing the risks of extreme events and disasters to advance climate change adaptation: Special report of the Intergovernmental
Panel on Climate Change. Cambridge: Cambridge University Press.

Jamshed, A., I.A. Rana, J. Birkmann, and O. Nadeem. 2017. Changes in vulnerability and response capacities of rural communities after extreme events: Case of major floods of 2010 and 2014 in Pakistan. Journal of Extreme Events 4(3): 1-29.

Janssen, M.A., and E. Ostrom. 2006. Resilience, vulnerability, and adaptation: A cross-cutting theme of the international human dimensions programme on global environmental change. Global Environmental Change 16(3): 237-239.

López-Martínez, F., S. Gil-Guirado, and A. Pérez-Morales. 2017. Who can you trust? Implications of institutional vulnerability in flood exposure along the Spanish Mediterranean Coast. Environmental Science \& Policy 76: 29-39.

Mazumdar, J., and S.K. Paul. 2016. Socioeconomic and infrastructural vulnerability indices for cyclones in the eastern coastal states of India. Natural Hazards 82(3): 1621-1643.

Miceli, R., I. Sotgiu, and M. Settanni. 2008. Disaster preparedness and perception of flood risk: A study in an Alpine Valley in Italy. Journal of Environmental Psychology 28(2): 164-173.

NDMA (National Disaster Management Authority). 2012. National disaster management plan 2012. Islamabad, Pakistan: National Disaster Management Authority.

Pandey, R., and S.K. Jha. 2012. Climate vulnerability index - Measure of climate change vulnerability to communities: A case of rural Lower Himalaya, India. Mitigation and Adaptation Strategies for Global Change 17(5): 487-506.

Papathoma-Köhle, M., B. Gems, M. Sturm, and S. Fuchs. 2017. Matrices, curves and indicators: A review of approaches to assess physical vulnerability to debris flows. Earth-Science Reviews 171: 272-288.

Phung, D., S. Rutherford, F. Dwirahmadi, C. Chu, C.M. Do, T. Nguyen, and N. Chi Duong. 2016. The spatial distribution of vulnerability to the health impacts of flooding in the Mekong Delta, Vietnam. International Journal of Biometeorology 60(6): 857-865.

Polsky, C., R. Neff, and B. Yarnal. 2007. Building comparable global change vulnerability assessments: The vulnerability scoping diagram. Global Environmental Change 17(3-4): 472-485.

Punjab Bureau of Statistics. 2014. Punjab development statistics 2014. Lahore: Punjab Bureau of Statistics. http://www.bos.gop. pk/publicationreports. Accessed 30 Oct 2017.

Rana, I.A., S.S. Bhatti, and S. Saqib. 2017. The spatial and temporal dynamics of infrastructure development disparity - From assessment to analyses. Cities 63: 20-32.

Rana, I.A., and J.K. Routray. 2016. Actual vis-à-vis perceived risk of flood prone urban communities in Pakistan. International Journal of Disaster Risk Reduction 19: 366-378.

Rana, I.A., and J.K. Routray. 2018. Integrated methodology for flood risk assessment and application in urban communities of Pakistan. Natural Hazards 91(1): 239-266.

Sadia, H., M.J. Iqbal, J. Ahmad, A. Ali, and A. Ahmad. 2016. Gendersensitive public health risks and vulnerabilities' assessment with reference to floods in Pakistan. International Journal of Disaster Risk Reduction 19: 47-56.

Saqib, S.E., M.M. Ahmad, S. Panezai, and I.A. Rana. 2016. An empirical assessment of farmers' risk attitudes in flood-prone areas of Pakistan. International Journal of Disaster Risk Reduction 18: 107-114.

Schröter, D., C. Polsky, and A.G. Patt. 2005. Assessing vulnerabilities to the effects of global change: An eight step approach. Mitigation and Adaptation Strategies for Global Change 10(4): 573-595.

Shah, A.A., J. Ye, M. Abid, J. Khan, and S.M. Amir. 2018. Flood hazards: Household vulnerability and resilience in disaster-prone 
districts of Khyber Pakhtunkhwa Province, Pakistan. Natural Hazards 93(1): 147-165.

Tate, E. 2012. Social vulnerability indices: A comparative assessment using uncertainty and sensitivity analysis. Natural Hazards 63(2): 325-347.

Terpstra, T., and J.M. Gutteling. 2008. Households' perceived responsibilities in flood risk management in the Netherlands. International Journal of Water Resources Development 24(4): $555-565$.

Thouret, J., S. Ettinger, M. Guitton, O. Santoni, C. Magill, K. Martelli, G. Zuccaro, V. Revilla, J.A. Charca, and A. Arguedas. 2014. Assessing physical vulnerability in large cities exposed to flash floods and debris flows: The case of Arequipa (Peru). Natural Hazards 73(3): 1771-1815.

Turner, B.L., R.E. Kasperson, P.A. Matson, J.J. McCarthy, R.W. Corell, L. Christensen, N. Eckley, J.X. Kasperson, A. Luerse, M.L. Martello, C. Polsky, A. Pulsipher, and A. Schiller. 2003. A framework for vulnerability analysis in sustainability science. Proceedings of the National Academy of Sciences of the United States of America 100(14): 8074-8079.

UNISDR (United Nations International Strategy for Disaster Reduction). 2004. Living with risk: A global review of disaster reduction initiatives. Geneva: UNISDR. http://www.unisdr.org/ we/inform/publications/657. Accessed 30 Oct 2017.

UNISDR (United Nations International Strategy for Disaster Reduction). 2009. UNISDR terminology on disaster risk reduction. Geneva: UNISDR. https://www.unisdr.org/publications. Accessed 30 Oct 2017.

Willroth, P., J.R. Diez, and N. Arunotai. 2011. Modelling the economic vulnerability of households in the Phang-Nga Province (Thailand) to natural disasters. Natural Hazards 58(2): 753-769.

Wisner, B., P. Blaikie, T. Cannon, and I. Davis. 2004. At risk: Natural hazards, people's vulnerability and disasters, 2nd edn. London: Routledge.

WMO (World Meteorological Organization). 2015. Seventeenth world meteorological congress, Geneva, 25 May-12 June 2015, Abridged final report with resolutions. Geneva: World Meteorological Organization. https://library.wmo.int/opac/doc_ num.php?explnum_id=3138. Accessed 02 Apr 2018.

Yoon, D.K. 2012. Assessment of social vulnerability to natural disasters: A comparative study. Natural Hazards 63(2): $823-843$.

Zhou, Y., Y. Liu, W. Wu, and N. Li. 2015. Integrated risk assessment of multi-hazards in China. Natural Hazards 78(1): 257-280. 